Imre Nóra - Török Balázs - Révész László

Eszterházy Károly Egyetem

\title{
A házi feladat szerepe a tanulási környezet alakításában
}

\author{
A Komplex Alapprogram fejlesztési tapasztalatai
}

Tanulmányunk egyrészt bemutatja, hogy az iskolai házi feladat témakörével foglalkozó nemzetközi szakirodalom milyen koncepciók mentén vizsgálja a házi feladat szerepét az tanulói eredményesség növelése, illetve az esélyegyenlóség biztositása érdekében. Másrészt felvázoljuk, hogy a házi feladat kérdésköre hogyan jelenik meg a tanórán kivüli tanulás összefüggésében, valamint az otthon és az iskola viszonyrendszerében. A házi feladat iskolai tanulási környezetbe illesztését elsósorban az oktatási intézmények délutáni idószervezésének figyelembevétele,

az ismeretek elmélyítését célzó tanórán kivüli feladatadás

gyakorlata, valamint az otthoni tanulási környezet szerepe alapján tekintettük át. A Komplex Alapprogramban részt vevó általános iskolákban a házi feladat szerepére irányuló kutatásunk lehetôvé tette, hogy feltárjuk az intézményvezetók, a pedagógusok

és a szülók véleményét a házi feladat jelentôségéról, szerepéról, szankcionálásáról. Vizsgálatunk eredményei azt mutatják, hogy a Komplex Alapprogram házi feladat eltörlésére irányuló javaslata elindította és/vagy felerôsítette a közös gondolkodást a házi feladat adásának gyakorlatáról. Kutatási szempontból érdekes helyzet adódott, ugyanis az intézmények olyan pedagógiai ajánlásokkal találkoztak, melyek követése vagy éppen korrekciója érdekében meg

kellett erốsiteniük, vagy esetenként ki kellett dolgozniuk szakmai álláspontjukat. Tanulmányunkban többek között bemutatjuk az intézmények eltérố reakcióit a pedagógiai módszertani fejlesztési program házi feladat adást érintố ajánlásaira.

\section{Bevezetés}

A házi feladat tanulási környezetbe integrálása a hazai szakirodalomban periférikus tématerületnek látszik. A házi feladat szerepével foglalkozó elemzések többnyire olyan mindennapos, bevált pedagógiai gyakorlatnak tekintik, amelynek nincsenek érdemi kapcsolódási pontjai más tématerületek, szakpolitikai megfontolások, vagy akár tudományos elemzések irányában. A témát érintő hazai szakirodalom felveti a házi feladatra fordított idő és a tanulói eredményesség kapcsolatát, de többnyire nem 
foglalkozik a házi feladat szerepével a tanórán kívüli tanulás kontextusában (Falus, 1998; Mihály, 2003; Imre és mtsai, 2015b; Márton, 2019). Az angol nyelven elérhető szakirodalomban több olyan tudományos elemzést találunk, melyek a házi feladatban a tanulmányi eredményesség növelésének egyik eszközét látják (Cooper és mtsai, 2001b; Cooper és mtsai, 2006a; Eilam, 2001). A témakör tágabb összefüggéseit vizsgáló kutatók a házi feladat szerepét az esélyegyenlőtlenség kontextusában vizsgálják, felhívva a figyelmet arra, hogy a különböző társadalmi hátterü tanulók eltérő erőforrásokkal rendelkeznek az otthoni tanulástámogatás tekintetében (Epstein és Voorhis, 2001; Bempechat és mtsai, 2011a), vagy hogy az alapfokú oktatásban az esélyek kiegyenlítése miként lehetséges a délutáni idősáv kihasználása révén (Cosden és mtsai, 2004b; Cummings és mtsai, 2007; Cummings és mtsai, 2011). Ezenfelül az elmúlt évtizedben a nemzetközi szakmai diskurzusban elötérbe került a tanulási környezet minősége (OECD, 2010; Lippman, 2010; OECD, 2017b) és a tanulói jóllét kérdése (OECD, 2016-2017, 2017a) a tanulói eredményesség összefüggésében.

Tanulmányunkban egyrészt oktatásszociológiai nézőpontból közelítünk a házi feladat témaköréhez, másrészt az országos jelentőségü Komplex Alapprogram megvalósítása során adódott tapasztalatok alapján vizsgáljuk meg a házi feladat pedagógiai gyakorlatba integrálásának kérdéskörét. A későbbiekben felvázoljuk azokat a rendszerszintü tényezőket, melyek meghatározzák a házi feladat oktatási integrációját, emellett bemutatjuk, hogy a házi feladat tématerület mely alapelvek mentén került be az angolszász szakpolitikai diskurzusokba. A tanulmány vázolja, hogy az atlanti oktatási rendszerek típusába sorolható országokban (Kozma, 2006) milyen törekvések figyelhetök meg - a házi feladathoz kapcsolódva - az eredményesség növelése, illetve az esélyegyenlőség biztosítása érdekében. Emellett bemutatjuk, hogy a házi feladat mint a tanórán kívüli tanulás egyik fontos formája hogyan jelenik meg a tanulók délutáni idősávjában, milyen kapcsolódási pontok érzékelhetők az iskola és az otthon viszonyrendszerében. Ezenfelül említést teszünk a házi feladat lehetséges hasznosulásáról, előnyeiről és hátrányairól.

A házi feladat oktatási szerepe érinti az iskolák délutáni idősávban kialakított tevékenységszervezését (pl. napközi, tanulószoba) és az otthoni tanulástámogatás eltérő lehetőségeit is. Elemzésünk során bemutatjuk azokat az intézményi szintü megoldásokat, melyeket a Komplex Alapprogram kipróbálási szakaszában részt vevő intézmények valósítottak meg a program ajánlására reagálva. ${ }^{1}$ Az intézményvezetői és a pedagógusi visszajelzések mellett beszámolunk azokról a szülői véleményekről és tapasztalatokról, melyek a házi feladat kérdéskörét érintik.

Tanulmányunk célja kettős: egyrészt bemutatja a házi feladat rendszerszintü kontextusát, másrészt egy konkrét pedagógiai-fejlesztési program vonatkozásában tárja fel a házi feladathoz kapcsolódó intézményvezetői, pedagógusi és szülői attitüdöket, nézeteket és tapasztalatokat. Ez utóbbi témakör hasznos lehet mindazon fejlesztési programok megvalósítói számára, akik a pedagógusok gyakorlatát olyan rutinizált területen kívánják alakítani, mint a házi feladat szokásrendje.

\section{Tanulói eredményesség, a tanulói jóllét és a tanulási környezet minőségének összefüggése a házi feladat kontextusában}

Az elmúlt évtizedekben - elsősorban az angolszász országokban - oktatáskutatók és szakpolitikusok, intézményvezetők, pedagógusok és szülök vitáztak a házi feladat hasznosságáról, előnyeiről és hátrányairól. Több kutatás számolt be az ezzel kapcsolatos eredményekről, a házi feladat iskolai teljesítményre gyakorolt hatásáról (Cooper és Valentine, 2001; Cooper és mtsai, 2001b; Cooper és mtsai, 2006a; Bempechat, 2004b; Hoover-Dempsey és mtsai, 2001; Bempechat és mtsai, 2011b). Az Egyesült Államok 
oktatáspolitikája az ezredforduló éveiben tette szakmai diskurzus tárgyává a házi feladattal kapcsolatos szakpolitikákat, gyakorlatokat. Többek között azért, mert ekkor került előtérbe az esélyegyenlőség és az eredményesség kérdése, illetve e két oktatáspolitikai cél közötti kapcsolat. Az oktatás minőségének elömozdítására tett stratégiai lépések egyik fő célja éppen az volt, hogy a tanulói eredményességet növeljék (No Child Left Behind, 2002), s ennek érdekében bevonják a szülőket a tanulásszervezésbe, akár éppen a házi feladat elkészítésének támogatásán keresztül (Folkard, 2007).

A házi feladattal ${ }^{2}$ kapcsolatos amerikai vizsgálatok egyik fő célja az volt, hogy a mindennapos pedagógiai gyakorlat irányítóit és a szakpolitikai döntéshozókat informálják a tanulók házi feladatot érintő optimális terhelési szintjéről, figyelembe véve a tanulmányi teljesítmények növelésének célkitüzését. Egy másik kutatási cél az volt, hogy segítsék a szülöknek megtalálni a megfelelő arányokat a házi feladat elkészítése és a harmonikus családi élet vezetése között (Cooper és mtsai, 2006a. 3.). A vizsgálatok eredményeként kimutatták, hogy az általános iskolákban a házi feladatok és a teszteredmények között kismértékű a korreláció, de a középiskolák esetében a két változó közötti kapcsolat pozitív és erősebb az előbbinél (Cooper és mtsai, 2001a). A kutatók többféle magyarázatot találtak a jelenség okainak feltárására. Az egyik, hogy a fiatalabb korosztály az iskolában valószínűleg hosszabb idő alatt végzi el a kiadott feladatokat, mivel a figyelmének fenntartása és fókuszálása korlátozottabb. Másrészt az általános iskolai tanulók tanulási készségei, tanulásmódszertani tudása alacsonyabb szinten áll, és az időbeosztásuk is bizonytalanabb. $\mathrm{S}$ végül kevésbé képesek figyelmen kívül hagyni a külső környezet befolyásait, ezért kevésbé hatékony náluk az otthoni tanulás (Cooper és mtsai, 2001b. 182.; Cooper és Valentine, 2001). Ezt követően egy szintetizáló munka (metaanalízis) eredményeként a házi feladat témakörében vizsgálódó kutatócsoport alátámasztotta a korábbi kutatási eredmények megállapításait, miszerint a házi feladat elkészítése pozitív összefüggést mutat az eredményességgel (Cooper és mtsai, 2006b. 48.). A felmérések a 7-12. évfolyamos diákok esetében mutattak ki szorosabb összefüggést. Ezenfelül a kutatók jelezték, hogy
A matematika kompetenciát fókuszba helyezó 2012-es PISA vizsgálat adatai szerint iskolai szinten összefüggések mutathatók ki a tanulók - iskolában és iskolán kívül - tanulással eltöltött idótartama és a tanulói teljesítmények között. Az oktatási rendszer szintjén azonban ezek nem egyértel-

múek, mivel az országok nagyon eltérốen kezelik a tanórán kívüli tanulásra eltöltött idô hosszát és annak eltöltésének módját (OECD, 2013-2014. 45.). Az adatok szerint a kedvezó szocio-ökonómiai hátterú tanulókat beiskolázó intézményekbe járó diákok hetente két órával többet töltenek házi feladat készitésével, mint a kedvezótlen társadalmi, gazdasági helyzetú tanulókat nagyarányban beiskolázó oktatási intézményekbe járó tanulók. A 2012-

es PISA vizsgálat azt az összefüggést is kimutatta, hogy akik több idót töltöttek el a házi feladat készitésével, jobban teljesitettek még akkor is, ha a diák szocio-ökonómiai helyzetét és demográfiai hátterét, valamint az iskola egyes változóit kivették az elemzésból. 
olyan longitudinális vizsgálatok szükségesek, melyek a tanulók kohorszát követik, és a házi feladat elvégzésével kapcsolatos tevékenység minőségét mélyrehatóbban elemzik (Cooper és mtsai, 2006b. 54.).

A tanulói teljesítményeket mérő nemzetközi összehasonlító felmérések szintén vizsgálták a tanórán kívüli tanulásra fordított idő mennyiségét az eredményességgel összefüggésben (OECD, 2013). A matematika kompetenciát fókuszba helyező 2012-es PISA vizsgálat adatai szerint iskolai szinten összefüggések mutathatók ki a tanulók iskolában és iskolán kívül - tanulással eltöltött időtartama és a tanulói teljesítmények között. Az oktatási rendszer szintjén azonban ezek nem egyértelműek, mivel az országok nagyon eltérően kezelik a tanórán kívüli tanulásra eltöltött idő hosszát és annak eltöltésének módját (OECD, 2013-2014. 45.). Az adatok szerint a kedvező szocio-ökonómiai hátterü tanulókat beiskolázó intézményekbe járó diákok hetente két órával többet töltenek házi feladat készítésével, mint a kedvezőtlen társadalmi, gazdasági helyzetü tanulókat nagyarányban beiskolázó oktatási intézményekbe járó tanulók. A 2012-es PISA vizsgálat azt az összefüggést is kimutatta, hogy akik több időt töltöttek el a házi feladat készítésével, jobban teljesítettek még akkor is, ha a diák szocio-ökonómiai helyzetét és demográfiai hátterét, valamint az iskola egyes változóit kivették az elemzésből. Az adatok mögött azonban azt is látni kell, hogy a különböző oktatási rendszerek, az egyes iskolák, sőt az egyes tanárok is nagyon eltérő gyakorlatot folytatnak a házi feladat kiadásával kapcsolatban. ${ }^{3}$

A tanulásra fordított idő és az eredményesség kérdésköre mellett a 2015-ös PISA nemzetközi felmérés a diákok iskolai közérzetét, jóllétét is vizsgálta. A tanulók tanulmányi teljesítményén túlmenően egy további dimenzió - az életminőség - vált elemzési szemponttá. A PISA 2015-ös adatfelvétele négy fö területen vizsgálta a 15 éves diákok jóllétét: (1) iskolai teljesítmény, (2) társakkal és a tanárokkal való kapcsolat, (3) otthoni élet, (4) az iskolán kívüli időtöltés formái (OECD, 2016-2017. 19.). A PISA vizsgálat kiindulópontja az volt, hogy ami az iskolában történik, az meghatározó fontosságú a tanulók jólléte szempontjából. ${ }^{4}$ A felmérés lehetőséget nyújtott a tanulmányi teljesítmény és a tanulói jóllét összefüggéseinek elemzésére. Az eredmények szerint gyenge negatív összefüggés van a természettudományos teszteken mért átlagos teljesítmény és a 15 éves tanulók élettel való elégedettsége között. Másképpen fogalmazva: az alacsony szintü teljesítményt mutató OECD-országok diákjai általában magasabb szintű elégedettségről számolnak be, mint a jól teljesítő országok diákjai. De vannak kivételek: pl. Finnországban, Hollandiában és Svájcban a tanulók átlag feletti teljesítményt nyújtanak a természettudományban, és nagyobb valószínüséggel számoltak be arról, hogy elégedettek az életükkel (OECD, 2016-2017. 73.). ${ }^{5}$

A felmérés további eredményei szerint az iskolában vagy azon kívül töltött tanulmányi idő és az élettel való elégedettség között nincs összefüggés. A tanulásra fordított több idő tehát nem jár alacsonyabb jóllét-szinttel. Összességében az látható, hogy nincs erős összefüggés a tanulmányi teljesítmény, a tanulásra fordított idő és a tanulók életminősége között. Tehát nem állítható, hogy a tanulási idő és ezzel együtt a házi feladatra fordított idő növelésével vagy csökkentésével önmagában befolyásolható lenne a tanulók közérzete. Mindezek mellett továbbra is élénk szakmai diskurzusok tárgya a tanuló közérzetének, lelki egészségének megőrzése, az élményközpontú oktatás és nevelés fontossága, és mindezekkel összefüggésben az iskolai és otthoni tanulási környezet minőségének kérdése. Feltehetően ezek a témafókuszok nem a tanulmányi eredményesség középpontba állítása révén alakulnak ki, hanem a modern társadalmakat jellemző fokozott individualizáció révén. A tanulók elvárása, hogy minél inkább egyedileg foglalkozzanak velük, tanulásukat a készségszintjüknek megfelelően vezérelve.

Egyes kutatások szerint a tanulási környezet minősége meghatározó a tanuló motivációinak és tanulmányi teljesítményének alakulásában (Lippman, 2010). Az OECD 
PISA vizsgálat alátámasztotta azt a közismert tézist, miszerint azok a diákok, akik nyugodt, csendes helyen tanulhatnak otthon, magasabb eredményeket értek el, szemben azokkal a tanulókkal, akiknél ez nem biztosított (OECD, 2016-2017. 178.). A tanulás fizikai környezete olyan feltételeket biztosíthat, amelyek javíthatják vagy éppen ronthatják a diákok tanulásának eredményességét. Megjegyzendő, hogy a tanulás helyhez kötöttségét - a tanulási tér fogalmát - az információs és kommunikációs technológiák (IKT) használata átalakíthatja (OECD, 2017b. 8.). Az IKT alkalmazásából eredő változások azonban nem egyértelműek. Vannak kutatási eredmények arra vonatkozóan, hogy a digitális technológiával készített házi feladatnál csökken a figyelem, a koncentráció (Flecha és mtsai, 2020. 45.). A COVID által előidézett járványhelyzetben is megfigyelhető volt, hogy az alapfokú oktatás digitális közvetítő médiumokra adaptálása egyes tanulók számára elönyöket, mások számára hátrányokat rejtett magában. A digitalizációval és a médiumok szerepének erősödésével összefüggésben néhány kutató azt javasolja, hogy a hatékony tanulás érdekében a szülők olyan tanulási környezetet hozzanak létre, ahol nem terelődik el könnyen a gyermek figyelme. A tanárok pedig részesítsék előnyben a releváns, minőségi szempontokat a házifeladat-adás során, szemben a mennyiségi tényezőkkel (Xu, 2015).

\section{A házi feladat - elönyök, hátrányok}

A vizsgálatok szerint a házi feladat - az eredményességgel való összefüggésén túl - a tanórán kívüli időben is tanulásra ösztönzi a tanulót, fejleszti tanulási szokásait és készségeit. Emellett elősegítheti az önszabályozó képesség, az önfegyelem kialakulását, amely összekapcsolódik a feladat elvégzéséhez füződő kötelességérzettel, felelősségtudattal, a rendelkezésre álló idő egyéni beosztásával (Cooper és mtsai, 2006a. 6.). Ezek a személyes készségek, jellemzők nemcsak a tanulmányi előmenetelhez szükségesek, hanem segíthetik a felnőttkori - az élethosszig tartó - tanulás megalapozását is, de az élet más, nem tanuláshoz kötődő területein is nélkülözhetetlenek. Mindezeken túl a házi feladat a szülök egy részénél növelheti a gyerek tanulásában való részvételi hajlandóságot, a pedagógus és a szülö közötti együttmüködés gyakoriságát, és közvetetten a tanuló iskolai elkötelezettségére is kedvező hatással lehet. A tanuló túlterhelése esetén a házi feladatnak kedvezőtlen hatása lehet, amely megnyilvánulhat a tanulás iránti csökkent érdeklödésben, érzelmi és fizikai kimerültségben. A házi feladat a tanuló iskolán kívüli környezetében is hozhat kontraproduktív eredményeket, mint például a szülők túlzott nyomásgyakorlása a feladatok helyes megoldása érdekében. Az erős szülői szigor és ellenőrzés negatív hatást gyakorolhat a tanuló tanulási motivációira és iskolai elkötelezettségére (Cooper és mtsai, 2001a). ${ }^{6}$ Ha a házi feladatot a tanuló időmérlegének kontextusában vizsgáljuk, arra a következtetésre juthatunk, hogy ami az iskolai elömenetel szempontjából elönyös, az más vonatkozásában hátrányt jelenthet. Lehetséges, hogy a házi feladat a testmozgástól, a személyiségfejlődéshez szükséges saját szabadidős tevékenységektől vonja el a tanulót.

A vizsgálatok hátterében a készségek és kihívások egyensúlyának koncepciója fedezhető fel. A tanulás akkor sikeres - flow-élmény közeli - a diák számára, ha a kihívások (feladatok) a tanuló számára sem nem túl könnyüek, sem nem túl nehezek (Oláh, 1999). A házifeladat-adás gyakorlata tehát az oktatási feladatadás pedagógiájának átfogó koncepciója alá illesztendő. E kutatási terület eredményei azt jelzik, hogy a házi feladat a tanulók jellemzőinek függvényében negatív és pozitív következményekkel is járhat. Ugyanazok a feladatok nagyon eltérő hatásokat válthatnak ki a különböző tanulási stílussal és képességszinttel jellemezhető diákokban (Cooper és mtsai, 2001b). A tanuló előzetes tudása, képességei, motivációi és az otthoni életkörülményei befolyásolják, hogy egyénileg milyen mennyiségü és típusú feladatok nyújtanak számára elegendő kihívást, biztosítják a továbbfejlődési lehetőséget, miközben elkerülhetővé teszik a kiégés 
veszélyét. Ezek a tapasztalatok és kutatási eredmények az egyéni feladatadás irányába terelik a pedagógiai gyakorlatot.

A házi feladat irányított egyéni munkaforma, ezért lehetőséget nyújt arra, hogy kialakítsa a tanulóban az önszabályozó tanulás folyamatát, a megküzdési képességet, a felelősségérzetet, az idővel való gazdálkodás képességét, s mindazokat a készségeket, melyek az ebben a tekintetben irányított tanórák alatt kevésbé szerezhetők meg. A házi feladat ösztönözheti a tanulót az önálló tanulásra, újfajta tanulási stratégiák kialakítására, s olyan módon fejleszti a figyelmet, hogy a tanuló képes lesz kizárni a tanulás során fellépő zavaró környezeti tényezőket (Epstein és Voorhis, 2001; Ramdass és Zimmerman, 2011).

Ha a házi feladat hasznosságát próbáljuk megítélni, akkor látható, hogy az iskola által külsőnek tekintett olyan exogén faktorok, mint a tanuló neme, évfolyama, képességei, egyéni motivációi, családi háttere mellett több olyan belső (pedagógiai) tényező is van, mely meghatározza a házi feladat hasznosíthatóságát és jelentőségét a tanuló iskolai életében. A tantervi elöírásokhoz való igazodás, az adott taneszközökhöz, tankönyvekhez való illeszkedés, valamint a különböző osztálytermi gyakorlatok és visszajelzések is befolyásolják a házi feladat eseti hasznosulását (Cooper és mtsai, 2006a).

\section{Tanórán kívüli tanulás - rendszerszintü kezdeményezések a délutáni idősávban}

A házi feladat egyik kockázati tényezőjeként szokták említeni az alacsonyan, illetve a kiemelkedően teljesítő tanulók közötti különbségek növekedését. Különösen a társadalomkritikai megközelítést ${ }^{7}$ alkalmazó elemzők azzal érvelnek, hogy a házi feladat gyakorlata a tanuló családjának szocio-ökonómiai hátterétől függően hasznosul, azaz erős az összefüggés a tanuló családjának társadalmi státusza és a házi feladat fejlesztő hatása között (Cooper és mtsai, 2006b). A magasabb tanulmányi eredményeket felmutató tanulók mögött sokszor áll kedvező társadalmi, gazdasági helyzetü család, tanulást támogató otthoni környezet és hatékonyabb, szakszerübb segítségnyújtás az iskolai tanulásban vagy bármely kognitív képesség kibontakoztatásában. És megfordítva, az alacsonyabb tanulmányi eredményeket felmutató tanulók családi háttere a tanulás támogatásában kedvezőtlenebb. A különbségek pedig éppen az otthoni feladatmegoldás - a házi feladat - révén erősödhetnek. A jelenség a tanulók időbeosztásában is tetten érhető: a délutáni időszakot a tanulók egy része „,kulcsos” gyerekként tölti, azaz a szülők és az iskola által ellenőrizetlenül, míg más gyerekek éppen túlfoglalkoztatottak, akiknek minden ideje be van osztva különfoglalkozásokkal és otthoni tanulással (Cosden és mtsai, 2004a). Megjegyzendő, hogy a tanuló családi hátterén túl erős befolyásoló tényezők a gyermek egyéni jellemzői, mint az életkora, a neme, egyéni képességei, motivációi és egyéni igényei. Mindezek alapján látható, hogy a délutáni időszak tanulás szempontjából hatékony eltöltése számos változótól függ.

A tanulói eredményesség növelésére irányuló törekvésekkel párhuzamosan egyre nagyobb hangsúlyt kaptak azok a szakpolitikai elvek, melyek a társadalmi integráció, illetve a méltányosság jegyében igyekeztek konkrét oktatásfejlesztési programokat megvalósítani. Az angolszász államokban számos olyan kezdeményezés valósult meg, melyek célzottan az intézmények gyakorlatának fejlesztésére irányultak. Itt említhetők meg az angol oktatásirányítás azon intézkedései, melyek a tanórákon kívüli - angol kifejezéssel az iskolán kívüli - délutáni idősávot igyekeztek lefedni. Ennek eredményeként az ezredfordulót követően sorra jöttek létre olyan oktatási intézmények, kiterjesztett vagy teljes szolgáltatást nyújtó iskolák, melyek, felkarolva a kedvezőtlenebb társadalmi és gazdasági családi hátterü gyerekeket, széles körben kínáltak különböző profilú foglalkozásokat a délutáni vagy esti órákban (Patall és mtsai, 2010; Dyson, 2011; Dyson és Kerr, 2014). 
Az OECD vizsgálataiból tudjuk, hogy a világ számos országában növekvő jelentősége van az olyan tanórán kívüli ún. extrakurrikurális foglalkozásoknak, melyek mindenki számára hozzáférhetők, választhatók, és intézményi szinten strukturálják a tanulók délutáni idősávját. Ezeknek a foglalkozásoknak a jellege azonban nagyon változatos képet mutat. Egyes országokban inkább a gyengébb tanulmányi eredményü tanulók felzárkóztatására helyezik a hangsúlyt, máshol nagyobb figyelmet fordítanak a különbözö intelligenciaterületekhez tartozó képességek kibontakoztatására (pl. zenei, testi-kinesztetikus, ld. OECD, 2013-2014). A különbségek arra vezethetök vissza, hogy az egyes országokban eltérő megtérülést feltételeznek az oktatási erőforrások kompenzatórikus és hatékonyság alapú felhasználásában. Ahol az oktatási rendszer összteljesítményének növekedését a kompenzatórikus funkciók erősítésétől remélik, ott a délutáni idősávban a kompenzációt helyezik előtérbe, míg ahol a hatékonyság növekedést a tehetségesebbek támogatásától várják, ott a programkínálat színesebb, több program érhető el a magas készségszintü tanulóknak.

A délutáni idősávot érintően többnyire olyan tevékenységekről van szó, mint a sportolás, zenélés vagy egyéb müvészeti tevékenységek, melyek elsősorban a nem-kognitív készségeket, például a szociális kompetenciát (pl. szabálykövetés, kitartás, együttmüködés másokkal) fejlesztik. Az ebben az idősávban megszerezhető készségek egyes kutatások szerint nagyobb eredményt hoznak a gyengébben teljesítő, iskolai kudarcokkal küzdő tanulók számára. Ezek a délutáni foglalkozások - az idő és a hely strukturáltsága folytán - pozitív hatást tudnak gyakorolni a részt vevő gyerekek önbecsülésére, iskolai elkötelezettségére és tanulmányi eredményeire (Cosden és mtsai, 2004a). Más tanulmányok ezt a direkt összefüggést nem igazolták, viszont jelezték, hogy a megcélzott tanulóknál a délutáni tanulástámogató foglalkozások megelőzhetik az iskolai teljesítmény romlását (Morrison és mtsai, 2000).

Több felmérés is igazolta, hogy a különböző extrakurrikuláris tevékenységek pozitív közösségi élményeket nyújtanak a tanulóknak, akik ezért szorosabban kapcsolódnak az iskolához. Ebből eredően az iskola iránti elkötelezettségük is erősödik, ami a korai iskolaelhagyás egyik fö védőfaktora (Hammond és mtsai, 2007). Egy európai uniós tanulmány szerint a lemorzsolódó diákok fö jellemzői közé tartoznak a következők: alacsonyabb fokú iskolai aktivitás, kevesebb házifeladat-készítés, több fegyelmezési probléma, kevesebb erőfeszítés a tanulásban, negatív attitüdök az iskola felé (European Commission, 2010. 25.). Mivel ezeknek a jelenségeknek egy része az iskolák által kezelhető, kontrollálható, ezért is jöttek létre pl. Angliában olyan iskolafejlesztési programok (Full Service Extended Schools, FSES), ${ }^{8}$ melyek a délelőtti tanítási időt nemcsak kitágították a délutáni időszakra, hanem minőségileg más jellegü foglalkozásokat, szolgáltatásokat kínáltak a tanulóknak, a családoknak és a helyi közösség tagjainak (Cummings és mtsai, 2007). Ezek a szakpolitikai kezdeményezések a gyakorlatban változó sikerrel jártak, de túlnyomórészt pozitív eredményekről számoltak be a tanulók szociális, érzelmi és viselkedési problémáinak alakulásában, a szülők aktivitásában, az iskolai légkörben (Cummings és mtsai, 2007).

Ami a gyakorlatot illeti, az iskolafejlesztési programok keretében több angolszász államban születtek ún. „,házi feladat klubok” (,homework clubs”) vagy „,iskolaidő utáni házifeladat-programok” („After-School Homework Programs”), melyek előnyeit és esetleges hátrányait azóta részletesen feltárta a szakirodalom (Cosden és mtsai, 2004b). Ezeknek a programoknak a legnagyobb előnye, hogy a házi feladatok megoldásához rendelkezésre áll - iskolai keretek között - a szakmai támogatás. Másodsorban csökkenti az ezzel kapcsolatos teendőket és az ebből adódó feszültségeket az otthon világában. Előnye még, hogy a tanuló látja, érzékeli kortársai erőfeszítéseit, ami megerősíti őt a tanulásban, és egyúttal megalapozhat, kifejleszthet benne új tanulási módszereket, készségeket (Cosden és mtsai, 2004b. 225.). 
Az angolszász országokban az iskolaidő utáni ún. „házifeladat-programok”9 egyik célja, hogy csökkentse a család terhét a házi feladat elkészítésének folyamatában. Ez többnyire azoknál a tanulóknál célravezető, akik kevesebb társadalmi és kulturális erőforrással rendelkeznek (pl. magánszféra szolgáltatásait az alacsony jövedelmi helyzetük miatt nem tudják igénybe venni), vagy a szülö bármilyen oknál fogva nem tud segíteni gyermekének a napi lecke elkészítésében. Másrészt sok szülő, aki nem tud felügyelni gyermekére munkaideje alatt, örül, ha ezt megoldottnak látja az iskolában. Ugyanakkor ennek a modellnek a másik oldala, hogy mivel a tanuló nem szorul rá az otthoni támogatásra, ez elvileg csökkenti a kommunikációs lehetőségeket az iskoláról a szülő és gyermeke között (Cosden és mtsai, 2004b).

\section{Tanulástámogatás - a szülői bevonódás eltérő lehetőségei}

A házi feladat alkalmazásának gyakorlata számos lehetőséget nyújt arra, hogy a tanulás iskolai és otthoni színtere összekapcsolódhasson egymással. A szülők ezen keresztül beleláthatnak az iskolában zajló folyamatokba, a tankönyveken keresztül a tananyag tartalmi elemeibe, a tanuló felé irányuló elvárásrendszerbe és bizonyos tekintetben az értékelési szempontokba. A gyereknek feladott írásbeli házi feladatokból és szóban elvárt lexikális tudásanyagból az érdeklődő szülő - a saját egyéni értelmezési szürőjén keresztül - benyomást szerez az iskoláról, az adott tanárról, illetve az általa elvárt - szaktárgyhoz kötött - kritériumrendszerről. Emellett a tanuló észleli a szülei által képviselt - tanuláshoz és iskolához füződő - értékrendet, a tanárok felé irányuló attitüdöket, ami visszahat a tanulási folyamatára. Egyes kutatások szerint a szülő érdeklődése, egyes tantárgyhoz, tananyaghoz mutatott kedvező viszonyulása pozitív összefüggést mutat a tanuló motivációival, ami megjelenik több házi feladat készítésében és a jobb tanulmányi eredményekben (Voorhis 2011).

A házi feladat mennyiségi kérdésein túl az elmúlt évtizedekben egyre több vizsgálat foglalkozott a szülők házifeladat-megoldásba való bevonódásának jelentőségével, az iskolai eredményekre gyakorolt hatásaival (Bempechat, 2004a; Walker és mtsai, 2004; Patall és mtsai, 2008; Voorhis, 2011; Ramdass és Zimmerman, 2011). Egy korábbi kutatás adatai szerint a szülői bevonódás, beleértve a házi feladatban való segítségnyújtást, összefüggést mutat a tanulói eredményességgel és az olyan személyes jellemvonásokkal (pl. önszabályozás, tanulmányi kompetenciák érzékelése), amelyek hozzájárulnak a magasabb teljesítményhez (Grolnick és Slowiaczek, 1994). Más vizsgálatok már differenciáltabb eredményre jutottak. Egy amerikai kutatás adatai szerint a középiskolai tanulóknál a különböző típusú támogatások eltérő előjelü összefüggést mutattak az iskolai eredményességgel. Az a szülői támogatás, amely elősegíti a tanuló autonóm munkavégzését, pozitív összefüggést mutatott az eredményességgel, míg a közvetlen, a konkrét feladattal kapcsolatos segítségnyújtás éppen ellenkezőleg, negatív összefüggést jelzett (Cooper és mtsai, 2001a. 197.). Hasonló eredményre jutott a szövegértés kompetenciát felmérö PISA 2009-es nemzetközi vizsgálat, amely megkérdezte a felmérésben részt vevő 15 éves tanulók szüleit arról, hogy milyen gyakorisággal segítenek a házi feladat elkészítésében. Az eredmények azt mutatták, hogy azok a diákok, akiknek rendszeresen segítenek a házi feladat elvégzésében otthon, alacsonyabb olvasási, szövegértési teljesítményt értek el (Borgonovi és Montt, 2012; OECD, 2016-2017). Ezeket az eltérő előjelü összefüggéseket a kutatók azzal magyarázták, hogy valószínúleg nem a szülö többlettámogatása okozza a gyengébb teljesítményt, hanem éppen ellenkezőleg: a szülő direkt beavatkozása a tanulási folyamatba már csak válasz a gyermek alacsonyabb tanulmányi eredményeire. Másrészt azok a tanulók, akik jól teljesítenek az iskolában, nem igénylik az otthoni támogatást. 
A szülöi hozzáállás a házi feladat elkészítéséhez nagyon változó mintázatot mutat. A bevonódás intenzitását többek között meghatározza a tanuló életkora, melyet alátámasztanak az angol kormányzat által kezdeményezett - rendszeresen lefolytatott - szülöi vizsgálatok eredményei is. Eszerint a szülők közel háromnegyede fontosnak tartja a házi feladatot, de ez az attitüd a tanuló évfolyamának emelkedésével csökkenő tendenciát mutat, mint ahogy a házi feladatban való konkrét segítségnyújtást is. Hasonlóan az elöbbihez a szülői magabiztosság is csökkenő tendenciát mutat az évfolyamok emelkedésével, de a többség még így is többnyire magabiztosnak tartja magát a házi feladatban való segítségnyújtásban (Mark és mtsai, 2008. 44-46.). Más kutatás adatai szerint az alacsonyabb iskolázottságú szülök alacsonyabb énhatékonyságot mutattak, kevésbé érezték magukat kompetensnek a segítségnyújtásban, mint a magasabb iskolai végzettségüek (Deslandes \& Rivard, 2013).

\section{A házi feladat intézménye a Komplex Alapprogram kipróbálási szakaszában}

A 2018/19-es tanévben bevezetett pedagógiai fejlesztési program egyik fö üzenete az élményközpontú nevelés és oktatás. Ezt a célt a program a tanulást támogató, újfajta pedagógiai módszerek eszközrendszerével igyekszik elérni. Ezek közé sorolható a délutáni idősávban kialakított, különböző kompetenciákat fejlesztő alprogrami foglalkozások ${ }^{10}$ köre, amely minden tanuló számára elérhető. A Komplex Alapprogram (KAP) azon túl, hogy érdekelt a korai iskolaelhagyás megelőzésében és mérséklésében, több olyan javaslattal él a programban részt vevő nevelési-oktatási intézmények felé, melyek befolyásolják a pedagógusok tanítás-tanulásszervezési módszereit, a délutáni idősáv tartalmi elemeit és a tanulók tanulásra fordított időtartalmának mennyiségét.

Ez utóbbi érinti a házi feladat alkalmazásának gyakorlatát, melynek fenntartását - a hagyományos keretek között - a program nem támogatja. ${ }^{11}$ Ezt a javaslatot a program bevezetésének első évét követően módosították, figyelembe véve a tanuló korcsoportját, illetve évfolyamát, de a házi feladat eltörlésének javaslatát nem írták felül. A Komplex Alapprogram intézményi megvalósítását
A matematika kompetenciát fókuszba helyezó 2012-es PISA vizsgálat adatai szerint iskolai szinten összefüggések mutathatók ki a tanulók - iskolában és iskolán kívül - tanulással eltöltött idótartama és a tanulói teljesítmények között. Az oktatási rendszer szintjén azonban ezek nem egyértel-

múek, mivel az országok nagyon eltérốn kezelik a tanórán kívüli tanulásra eltöltött idô hosszát és annak eltöltésének módját (OECD, 2013-2014. 45.). Az adatok szerint a kedvezó szocio-ökonómiai hátterú tanulókat beiskolázó intézményekbe járó diákok hetente két órával többet töltenek házi feladat készitésével, mint a kedvezótlen társadalmi, gazdasági helyzetú tanulókat nagyarányban beiskolázó oktatási intézményekbe járó tanulók. A 2012 -

es PISA vizsgálat azt az összefüggést is kimutatta, hogy akik több idót töltöttek el a házi feladat készitésével, jobban teljesitettek még akkor is, ha a diák szocio-ökonómiai helyzetét és demográfiai hátterét, valamint az iskola egyes változóit kivették az elemzésból. 
támogató Útmutató 2. kiadása tartalmazza mindazokat a változtatásokat, melyeket a program első (kipróbálási) évének tapasztalatai alapján a program vezetése kialakított. Ezek a módosítások azt jelzik, hogy a program érzékenyen reagált az intézményi megvalósítás során fellépő nehézségekre, s törekedett arra, hogy a visszajelzések alapján korrigálja a megvalósítási útmutatókat. A házi feladat témaköre kapcsán az alábbi módosító javaslat született, mely már különbséget tett az alsó és felső tagozatra járó tanulók célcsoportja között:

„Legyen-e házi feladat az alsó tagozatos tanulók számára az Élménysuliban? A rövid válasz, hogy lehetőség szerint ne legyen! A Komplex Alapprogramot bevezető iskolák esetében alsó tagozatban (1-4. évfolyam) nem javasolt a házi feladat feladása, helyette az alprogramok, a Komplex órák és a »Te órád « kiválthatják a házi feladat célját és tartalmát. Felső tagozatban (5-8. évfolyam) lehetőség szerint ne legyen házi feladat, hanem a tananyag függvényében szorgalmi feladat, vagy a tananyag alkalmazását segítő tanulói projekt vagy egyéb feladat." (Révész és Mizera, 2019. 61.)

A házi feladat alkalmazása helyett tehát azt javasolta a program, hogy a délutáni alprogrami foglalkozások töltsék be az eddigi hagyományos házi feladat ${ }^{12}$ megírására szánt foglalkozások funkcióját. A program által bevezetett délutáni foglalkozások (alprogramok, „Te órád”) keretében történjen meg a tanult ismeretek elmélyítése, alkalmazása (Révész és Mizera, 2019. 61.). Az új pedagógiai, fejlesztési program az élményközpontúság elvét szem előtt tartva arra törekszik, hogy a házi feladat klasszikus funkciójának számító bevésődést, rögzítést megtartsa a délelőtti tanórai keretek között. A szorgalmi feladatot ugyanakkor nem törli el, és ezzel a házi feladat kötelező elemét kiveszi a tanítás-tanulásszervezés rendszeréből. Emellett azzal, hogy beemeli a délutáni idősávba az alprogrami foglalkozások széles repertoárját, tanulástámogató környezetet nyújt - többek között - a kedvezőtlen társadalmi hátterü tanulók számára.

\section{A vizsgálat mintája, módszerei}

A házi feladat témakörét a Komplex Alapprogram kipróbálási szakaszában (2018/19es tanév) vizsgáltuk, melynek során a részt vevő intézmények (68 intézmény) körében több célcsoportra irányuló kvantitatív és kvalitatív adatfelvételre került sor. ${ }^{13} \mathrm{~A}$ tanév végén egyéni, félig strukturált interjúkat készítettünk a mintába ${ }^{14}$ került intézmények intézményvezetőivel $(n=50)$ és a KAP programban részt vevő pedagógusokkal $(n=50)$. Emellett év közben fókuszcsoportos interjúkra $(n=33)$ került sor a 4. évfolyamos tanulók szüleivel. ${ }^{15}$

Mindhárom célcsoportot arról kérdeztük, hogyan változott a házifeladat-adás gyakorlata a Komplex Alapprogram bevezetésével. Intézményi szinten az iskolavezető nyilatkozott arról, hogy a program javaslatát, miszerint ne legyen házi feladat, beépítették-e a gyakorlatba, s ha igen, hogyan. A programban résztvevő pedagógusoktól azt kérdeztük, hogy a vizsgált tanévben adtak-e házi feladatot a tanulóknak, s ha igen, akkor ezeket milyen keretek között. S végül megkérdeztük a szülöket, hogy kap-e a gyermeke házi feladatot az iskolában, s ha igen, hol oldja meg ezeket. Mindhárom célcsoport visszajelzést nyújtott arról, hogy mit gondol a házi feladat szerepéről, annak mellőzéséről, s a gyakorlat ennek megfelelö átalakulásáról. 


\section{Hazai intézményi tapasztalatok a KAP program ajánlása kapcsán}

A Komplex Alapprogram házi feladattal kapcsolatos javaslata eredetileg egységesen érintette a programba belépett oktatási intézmények müködésmódját (Révész és Mizera, 2018). A program bevezetésének második évében - a kipróbálási szakasz kutatási eredményeit, szakmai tapasztalatait beépítve - ez a javaslat annyiban változott, hogy különbséget tett az alsó, illetve a felső tagozat tanulásszervezési gyakorlata között. A köznevelési rendszerben a nappali rendszerü iskolai oktatás része a napközis és tanulószobai foglalkozás: az előbbi jellemzően az alsó tagozaton, az utóbbi a felső évfolyamokon müködik. A délután 4-ig tartó iskola bevezetésével ${ }^{16}$ - a 2013/14-es tanévtől - rendszerszinten biztosítottá vált a tanulók délutáni tanulása és felügyelete.

A programban részt vevő intézmények meghatározó része napközit tart fenn a délutáni idősávban (78\%), kisebb arányban (29\%) iskolaotthonos, egész napos iskola ${ }^{17}$ formájában valósítja meg az oktatást-nevelést. ${ }^{18}$ Mindkét esetben a 1-4 évfolyamra járó tanuló meghatározó része bent marad délután az iskolában, mialatt - a hagyományos gyakorlat szerint - a délelőtti tanórákon kiadott házi feladatokat oldják meg.

A Komplex Alapprogramot a kipróbálási szakaszban 4. évfolyamon vezették be, ahol alapvetően egy már meglévő intézményi struktúrához és gyakorlathoz (pl. napközi, iskolaotthon) kellett illeszteni a házi feladat intézményével kapcsolatos KAP-os állásfoglalást. A kvalitatív vizsgálat tapasztalatai szerint az intézmények eltérő válaszokat adtak a KAP program által javasolt, a házi feladat eltörlésére vonatkozó koncepcióra. Kutatási szempontból kiemelten érdekes helyzet adódott, ugyanis az intézmények olyan pedagógiai ajánlásokkal találkoztak, amelyek követése vagy éppen korrekciója érdekében meg kellett erösíteniük vagy ki kellett dolgozniuk szakmai álláspontjukat.

A kutatási adatok azt jelzik, hogy az intézmények reakciója jellemzően annak függvényében alakult, hogy az adott iskola milyen délutáni idősávra vonatkozó tanulásszervezési módot (napközi/tanulószoba vagy egész napos iskola) valósított meg. Ahol az intézmény iskolaotthonos, egész napos iskolaként $(\mathrm{n}=16)$ müködött, ott a délelötti-délutáni időszakra elosztott tanórai foglalkozások miatt korábban sem volt házi feladat. A többi vizsgált iskolában $(\mathrm{n}=34)$ pedig a napközi keretében oldották meg a gyerekek a házi feladatokat ${ }^{1}$.

A Komplex Alapprogram bevezetésével nagymértékben átalakult az iskolák délutáni idősávjának struktúrája. Az új alprogrami foglalkozások megvalósításával nemcsak a délutáni foglalkozások tartalma változott meg, hanem időben is átalakult a gyerekek délutáni időbeosztása. A legtöbb iskolában a már meglévő szakkörökre épültek rá az alprogrami foglalkozások, de volt, ahol teljes tartalmi újdonságot és élményszerüséget hoztak a KAP-os foglalkozások. A terepmunka tapasztalatai szerint a házi feladat intézménye ebben a délutáni időkeretben nehezen tartható. A Komplex Alapprogram javaslata erre az, hogy a tanórai gyakorlás mellett a délutáni alprogrami foglalkozások során dolgozzák fel - élményszerüen, alkalmazás közben - a tanulók a délelőtti tananyagot. Így a klasszikus házi feladatra jellemző direkt fejlesztésre nincs szükség (Révész és Mizera, 2019. 61.).

${ }^{1}$ A tapasztalatok szerint jellemzően az írásbeli házi feladatok készülnek el, a szóbeli (olvasás, verstanulás stb.) feladatok többnyire otthonra maradnak (Imre és mtsai, 2015a). 


\section{Intézményvezetői és pedagógus visszajelzések}

A tanév végén lefolytatott kvalitatív vizsgálat eredményei arra mutatnak rá, hogy a programot bevezető intézmények döntő többségében nem történt változás a házi feladat kiadásának gyakorlatában. A felmérésbe bevont 50 intézményböl 16-ban (egész napos iskola) korábban sem volt házi feladat, a többi iskola esetében vagy változatlanul megmaradt a házi feladat gyakorlata (napköziben), vagy egy bizonyos mértékủ átrendeződés történt a feladatok kiadásában. A KAP által javasolt teljes váltás, a házi feladat mellőzése hat intézménynél történt meg (1. táblázat). Az interjúk alapján az látható, hogy ebben a hat iskolában intézményvezetői döntésre alakult át a házifeladat-adás gyakorlata. Ugyanakkor nem fedezhető fel olyan intézményi sajátosság (pl. hátrányos helyzetü tanulók aránya), amely közös jellemzőként magyarázná a házi feladat eltörlésének okát (a KAP ajánlást kivéve). Másrészt ezek az iskolák mégis fenntartották a házifeladat-kiadás gyakorlatát, de nem kötelezően, hanem választható módon, szorgalmi feladatként.

„Ez az iskola már a KAP előtt is foglalkozott a házi feladat kérdésével. És már előtte is kértem a kollégákat, akik hajlandóak elfogadni az én vezetésemet, hogy bizonyos másfajta módszerekkel álljanak hozzá, hogy péntek délután ne adjanak hétvégére házi feladatot. És amit a KAP ajánl, azokat én majd próbálom még jobban tudatosítani, meg hát segítség, hogy le is van írva, és ez máshol is így müködik." (intézményvezető)

A kvalitatív vizsgálat eredményei szerint az intézmények többsége $(\mathrm{n}=28)$ megtartotta a házifeladat-adáshoz kapcsolódó korábbi gyakorlatát (1. táblázat). Közülük néhány iskola a program koncepcióját követve a tanév elején eltörölte a házi feladatot, de időközben - a következményeket mérlegelve ${ }^{20}$ - visszaállította azt. A kvalitatív vizsgálat tapasztalatai arra mutatnak rá, hogy az iskolák a délutáni idősávban, az alprogrami foglalkozások mellett mégis kialakítanak egy idősávot (pl. „Te órád”), hogy többé-kevésbé fenntarthassák az egyéni feladatmegoldásra, gyakorlásra szánt időt.

1. táblázat. A házi feladat intézménye a Komplex Alapprogram bevezetése elött és után intézményenként $(n=50)$

\begin{tabular}{|c|c|c|c|}
\hline \multirow{2}{*}{$\begin{array}{l}\text { Házi feladat } \\
\text { intézménye }\end{array}$} & & $\begin{array}{l}\text { Komplex Alapprogram } \\
\text { bevezetése előtt }\end{array}$ & $\begin{array}{l}\text { Komplex Alapprogram } \\
\text { bevezetése után }\end{array}$ \\
\hline & & $\mathbf{N}$ & $\mathbf{N}$ \\
\hline \multirow{2}{*}{$\begin{array}{l}\text { Házi feladat } \\
\text { nincs }\end{array}$} & $\begin{array}{l}\text { Egész napos iskola } \\
\text { iskolaotthon }\end{array}$ & 16 & 16 \\
\hline & KAP koncepció követése & - & 6 \\
\hline Összes & & 16 & 22 \\
\hline \multirow{2}{*}{$\begin{array}{l}\text { Házi feladat } \\
\text { van }\end{array}$} & $\begin{array}{l}\text { Házi feladat intézménye } \\
\text { hagyományos formában }\end{array}$ & 34 & 10 \\
\hline & $\begin{array}{l}\text { Házi feladat csökkentett, } \\
\text { módosított formában }\end{array}$ & - & 18 \\
\hline Összes & & 50 & 50 \\
\hline
\end{tabular}

Forrás: saját szerkesztés 
A Komplex Alapprogram ajánlása nyomán ezeknek az iskoláknak egy része $(\mathrm{n}=18)$, átgondolva a program ajánlásait, változtatott a házifeladat-adás gyakorlatán. Ez a változás érintette a házi feladat mennyiségét, időbeli szabályozottságát, szankcionálását. Elmozdult a gyakorlat afelé, hogy a pedagógusok kevesebb házi feladatot adnak fel (hétvégére nem adnak), egyes iskolákban az alprogrami foglalkozásokon részt vevő tanulóknak nem kötelező jelleggel adnak feladatot, $\mathrm{s}$ az el nem készült házit nem szankcionálják. Emellett a KAP-os órákon (DFHT, DFHT-KIP), ami a tanórák 20\%-át érinti, nem adnak fel házi feladatot. Ugyanakkor a legritkább esetben találkozunk olyan gyakorlattal, amilyet a KAP koncepció javasol, miszerint az alprogrami foglalkozások teret adnának egyfajta gyakorlásnak. Úgy tünik, a pedagógusok túlnyomó része nem tudja összekapcsolni az élményszerü tanítást-tanulást a gyakoroltatással. Úgy látják, hogy alsó tagozaton, föként az 1-2. évfolyamon elengedhetetlen az alapkészségek (olvasás, írás, számolás) kialakítása, ami szerintük csak folyamatos, ismételt gyakorlással érhető el.

$\mathrm{Az}$ intézményvezetői interjúk alapján elmondható, hogy az iskolák jelentős része törekedett a KAP házi feladattal kapcsolatos koncepciójának a követésére, de a hagyományos gyakorlat mellett felhozott érvek legtöbbször erősebbnek bizonyultak. Mind az iskolavezetők, mind a pedagógusok azokra az alapkompetenciákra (írás, olvasás, számolás) hívták fel a figyelmet, melyek csak gyakorlás során válnak készségszintü tudássá. Ezért is indult meg egy olyan folyamat, hogy ezentúl nem házi feladatnak nevezik el az alsó tagozatos tanulóknak kiadott feladatokat, hanem gyakorló feladatnak. Ebben az értelemben csak látszólag történt váltás: a fogalmak a szakmai elvárások érzékelésének megfelelően átalakultak, ami egyfajta adaptációs folyamatot jelez, de a házi feladat eredeti funkciója változatlan formában megmaradt.

A kvalitatív vizsgálat eredményei szerint az iskola házi feladattal kapcsolatos iránymutatása, szakmai dokumentumai (pl. pedagógiai program) meghatározzák a pedagógus konkrét gyakorlatát (pl. a másnapra vagy hétvégére feladott házi feladat mennyiségét), másrészt a szülőkkel való kapcsolódás intenzitását. Az intézményvezető ebben a tekintetben kulcsszereplő, de jellemzően a nevelötestülettel együtt hoz döntést, ami lehet az is, hogy szabad kezet kap a pedagógus a házi feladat kiadásának gyakorlatában. A tanári autonómia lehetőséget nyújt arra, hogy a pedagógus egyénileg szabályozza, hogyan, milyen formában és mennyiségben ad ki házi feladatot diákjainak.
Az intézményvezetôi interjúk alapján elmondható, hogy az iskolák jelentós része törekedett a KAP házi feladattal kapcsolatos koncepciójának a követélat mellett felhozott érvek. legtöbbször erósebbnek bizonyultak. Mind az iskolavezetók, mind a pedagógusok azokra az alapkompetenciákra (írás, olvasás, számolás) hívták fel a figyelmet, melyek csak gyakorlás során válnak készségszintú tudássá. Ezért is indult meg egy olyan folyamat, hogy ezentúl nem házi feladatnak nevezik el az alsó tagozatos tanulóknak kiadott feladatokat, hanem gyakorló feladatnak. Ebben az értelemben csak látszólag történt váltás: a fogalmak a szakmai elvárások érzékelésének megfelelóen átalakultak, ami egyfajta adaptációs folyamatot jelez, de a házi feladat eredeti funkciója változatlan formában megmaradt. 
„Hát mi változtattunk volna, de a pedagógusok fejében ez nem így müködik, hogy akkor mostantól megtiltjuk nekik, hogy ne legyen házi feladat, mert a szülők is, amikor próbálkozás erre történt, jöttek, hogy mi az, hogy nincs házi feladat? Nekik az a fontos, hogy a gyerek a tananyagot tudja, mert ebből fog majd felvételizni, meg ez kell neki a továbbtanuláshoz. És teljesen igazuk van, nehéz beláttatni a szülőkkel azt, hogy azok a [Komplex Alapprogram-os] megerősítő tevékenységek - a készségek, képességek fejlesztése - is az ő gyerekeinek a javát és a többlet tudását fogja majd szolgálni, ehhez még ez kevés idő." (intézményvezető)

A pedagógus interjúk - hasonlóan az intézményvezetői interjúkhoz - azt mutatják, hogy az új KAP-os programjavaslat elindította vagy felerösítette a közös gondolkodást a házi feladat kiadásának gyakorlatáról, annak előnyeiröl és hátrányairól. Köztudott, hogy a pedagógiai folyamat egyik leginkább vitatott jelenségéről van szó. A tanár egyrészről strukturálja és számon kéri az általa kiadott feladatokat. Ehhez igénybe veszi nemcsak az előzetes tartalmi és módszertani tudását, hanem kapcsolódik azokhoz a taneszközökhöz, amelyek rendelkezésére állnak. Áttételesen generálja és irányítja a tanuló tanulási folyamatát, amely a tanórán kívül valósul meg, akár iskolai keretek között, akár otthon. A házi feladat kiadásával nemcsak a tanulót szólítja meg, hanem az iskolában dolgozó kollégákat (pl. napközis és tanulószobás tanár), a délutáni idösávban az iskola keretein belül tanuló diákközösséget, valamint a tanuló életkorától, képességeitől függően a családot is.

A kvalitatív vizsgálat eredményei azt mutatják, hogy a pedagógusok a házi feladatnak inkább az előnyeit látják, ami a tanórákon átadott új ismeretek elmélyítését szolgálja követve azt az oktatási célt, hogy a tanuló a tanórán szerzett ismereteket újra áttekintse és gyakorolja. Az, hogy milyen szinten differenciál ebben a folyamatban a pedagógus, mennyire veszi tekintetbe a tanulócsoportok, az egyes tanulók sajátosságait, már az egyéni szakmai profiljától függ. Jellemző, hogy az alsó tagozaton az alapkompetenciák fejlesztését tekintik célnak, míg felső tagozaton az önálló feladatvégzést és a felelősségtudat kialakítását helyezik előtérbe. A házi feladat minőségi (tartalmi) elemei mellett mindig felmerül a mennyiségi szempont, amelyben úgy tünik, elmozdulás történt. Többen megfogalmazták, hogy csökkentették a kiadott feladatok számát, annak ellenére, hogy a tantervi elöírások nem ezt vetítenék elöre.

A pedagógusok visszajelzései szerint a Komplex Alapprogramban érintett tanulók örülnek, hogy délután többet játszhatnak, kevesebb vagy nincs házi feladat (pl. DFHT-KIP-es órákhoz kapcsolódóan). A délutáni idősávba azonban új alprogrami foglalkozások kerültek, így jóval kevesebb idő jut a gyakorló feladatokra, melyeket az intézmények többsége $(n=28)$ mégis fenntart. A szülöi igények, elvárások a program új koncepciójától függetlenül fennmaradtak, azokat az intézmények az új gyakorlatuk kialakításánál figyelembe vették. Az ambiciózus szülők - a továbbtanulás érdekében elvárják az iskolai gyakoroltatást, és ezzel párhuzamosan rendszeresen foglalkoznak, tanulnak otthon gyermekükkel. Ugyanakkor vannak olyan szülöi csoportok, amelyek kevéssé figyelnek gyermekük tanulására, s otthon nincs meg az a tanulástámogató környezet, amely a feltétele lenne a házi feladatok elvégzésének. Az egész napos oktatás, a napközi ugyanakkor biztosítja a délutáni tanulás lehetőségeit, de ismert, hogy sokszor maradnak szóbeli (olykor írásbeli) feladatok is otthonra. S ez már a szülő erőforrásait érinti, hogy mennyi ideje, energiája, affinitása van az esti órákban iskolai feladatok elkészítésére, gyakorlásra. 


\section{Szülői tapasztalatok és visszajelzések a házi feladatról}

A szülői fókuszcsoportos interjúk tanúsága szerint a szülök nem egységesek a házi feladat kérdésében. A legintenzívebb véleménynyilvánítók csoportjába a magasan kvalifikált, gyermekük taníttatása tekintetében ambiciózus szülök tartoztak. A házi feladat eltörlése vagy helyettesítése vonatkozásában véleményük közös eleme: tartanak attól, hogy gyermekük tanulmányi előrehaladása nem lesz olyan intenzív, ahogy ezt a standard felvételi követelmények megkívánják. A házi feladat eltörlésének híre esetükben ellenvéleményt, iskolakritikát generált, vagy legalábbis feszültséget keltett. Egyes szülők látásmódjának komplexitását jelzi, hogy egyszerre fogalmazták meg aggodalmukat a magas tantervi követelmények és az elmaradó gyakorló (házi) feladatok miatt. A fegyelmet nagyra értékelő, elvárásokat hangoztató szülők a gyermek kudarc- és monotóniatürését hasznosnak gondolják, és láthatóan idegenkednek a tanulás élményszerüségének túlhangsúlyozását követő pedagógiai gyakorlattól. Ugyanakkor látható az is, hogy a szülök nincsenek az élményközpontú tanulás ellen, mivel minden szülő alapvetően azt szeretné, ha gyermeke az iskolában jól érezné magát.

Mivel a KAP házi feladattal kapcsolatos koncepciója az intézményi adaptációtól függött, ezért különböző intézményi gyakorlatokat generált. Ennek megfelelően a szülői visszajelzések is eltérőek attól függően, hogy a gyermek iskolája, tanára milyen gyakorlatot valósít meg. Ahogy láttuk, a Komplex Alapprogramba belépett iskolák túlnyomó része csupán módosította a házifeladat-adás gyakorlatát, ami a szülöi ellenállást mérsékelhette.

A házi feladatot érintő változások egyik jellemző oka, hogy a délutáni idősávban éppen a házi feladat elkészítésére szánt időszakra épültek rá a Komplex Alapprogram alprogrami foglalkozásai. A legtöbb iskolában hibrid idő és tevékenységstruktúra alakult ki: megmaradt - ha módosult formában is - a házi feladat, és megjelentek a KAP-os élményalapú foglalkozások. Ez mind a pedagógusnak, mind a tanulónak nagyobb leterheltséget jelentett, amiről a szülök is beszámoltak.

Azoknál az iskoláknál, ahol eltörölték a házi feladatot, a fókuszcsoportos interjúkon részt vevő, túlnyomórészt ambiciózus szülők jelezték, hogy az új koncepció szerint
A legintenzívebb véleménynyilvánitók csoportjába a magasan kvalifikált, gyermekük tanittatása tekintetében ambiciózus szülók tartoztak. A házi feladat eltörlése vagy helyettesitése vonatkozásában véleményük. közös eleme: tartanak attól, hogy gyermekük tanulmányi elórehaladása nem lesz olyan intenziv, ahogy ezt a standard felvételi követelmények megkivánják. A házi feladat eltörlésének hire esetükben ellenvéleményt, iskolakritikát generált, vagy legalábbis feszültséget keltett. Egyes szülók látásmódjának komplexitását jelzi, hogy egyszerre fogalmazták meg aggodalmukat a magas tantervi követelmények és az elmaradó gyakorló (házi) feladatok miatt. A fegyelmet nagyra értékeló, elvárásokat hangoztató szülók a gyermek kudarc-és monotóniatúrését hasznosnak gondolják, és láthatóan idegenkednek a tanulás élményszerú-

ségének túlhangsúlyozását követó pedagógiai gyakorlattól. 
az otthoni gyakorlásra fordított idő megnövekedett annak érdekében, hogy könnyebb legyen a felső tagozatra való átállás és a középiskolai felvételi vizsgára való felkészülés. Többségük úgy látja, hogy az alapkészségek (olvasás, írás, számolás) elsajátítására az iskolában nincs elég idő. S mivel nincs kötelezően kiadott házi feladat, ezért nincs meg a délutáni önálló munkavégzés, s így a kötelességtudat kialakítása is nehezebb.

„...a mindennapos az, hogy hazaérünk és minimum fél hatig ott ülünk még az asztalnál és olvasunk és írunk. Ha nem írunk, akkor olvasunk fél hatig, tehát ennek óriási nagy hiánya van [az iskolában].” (Szülö)

„Hát ugye szorgalmi feladatnak meg ajánlott feladatnak van feltűntetve, de hát én mondom otthon a gyereknek, hogy a szorgalmi feladat az ugyanolyan, mint a házi feladat, csak másként hívják..." (Szülö)

A délutáni idősávban azok az intézmények, ahol fennmaradt a házi feladat intézménye, szülők többsége elfogadta az ezzel járó változásokat. A szóbeli gyakorlás (pl. verstanulás, olvasás) egy része otthonra marad, de nehezíti a helyzetet, hogy a tapasztalatok szerint a 4. évfolyamos tanulók a foglalkozások után fáradtabban érkeznek haza. Emellett van egy szülői réteg, ahol este nem tudnak vagy nem akarnak foglalkozni a gyermek tanulásával: ott elmarad a szóbeli gyakorlás, s ezzel a tanuló hátrányos helyzetbe kerülhet, mert a pedagógus többnyire számol a szülők erőforrásaival. A KAP koncepció értelmében ez nem következhet be, mert a házi feladat eltörlésével nem marad otthonra feladat. Meg kell említeni, hogy a programba belépő egész napos iskolák évek óra így müködnek, megadva az esélyt azoknak a tanulóknak is, akik kedvezőtlen szocio-ökonómiai családi háttérrel rendelkeznek.

\section{Összegzés}

Az elmúlt közel egy évtized során Magyarországon is egyre jelentősebb szerepet játszik az általános iskolai keretek között megvalósuló délutáni tanulás. Ez egész napos iskolaszervezési formában, vagy napközi és tanulószoba keretében valósul meg, s ez alól csak az a tanuló kaphat felmentést, akinek a szülője kérelmezi ezt. A szakirodalomból az tünik ki, hogy a különböző délutáni foglalkozásokat azért tartják elönyösnek, mert pozitív közösségi élményeket nyújtanak a tanulóknak, ezáltal iskolai elkötelezettségük erösödhet, amivel a korai iskolaelhagyás jelensége megelőzhető. Ennek jegyében született meg a Komplex Alapprogram koncepciója, mely az élményközpontú oktatást helyezte előtérbe, s ez a délutáni idősávot is érintette. A program szerint az újonnan bevezetett délutáni alprogrami foglalkozások játékos formában fejlesztik a tanulók képességeit. A házi feladat eltörlésének gondolata is ebbe a koncepcióba illeszkedik, melynek megvalósítása eltérő módon ment végbe a programot adaptáló intézményekben. Azt, hogy a házi feladat mellőzése milyen módon és mértékben valósult meg, meghatározta az adott iskola pedagógiai profilja, tanulásszervezési gyakorlata és - mint elemzésünk jelezte - a szülök elvárása, véleménynyilvánítása, aktivitása.

Vizsgálatunk eredményeként megállapítható, hogy alapvetően három kategóriába sorolhatók a Komplex Alapprogramba belépett intézmények a házi feladat kérdésköre szempontjából: (1) nem változtattak a meglévő gyakorlatukon, (2) módosítottak a meglévő gyakorlatukon, de nem törölték el a házifeladat-adás gyakorlatát, (3) a KAP koncepciónak megfelelően kivonták a házifeladat-adást a pedagógiai eszközrendszerükből. A legkisebb mértékü változás az egész napos iskolaként müködő intézményeknél $(\mathrm{n}=16)$ figyelhető meg, ahol a tanulási folyamatot korábban is házi feladat nélkül 
szervezték. A többi intézmény $(\mathrm{n}=34)$ esetében érzékelhető változás, de ennek mértéke nem teremt alapvetően új pedagógiai gyakorlatot. Kisebb mértékü változást tapasztaltunk, ahol igyekeztek megörizni a házi feladat intézményét, és erre időkeretet tartottak fenn a délutáni idősávban $(\mathrm{n}=10)$. Nagyobb változást figyelhettünk meg azokban az iskolákban, ahol nagyobb hangsúlyt fektettek az Komplex Alapprogram alprogrami foglalkozásaira, de csökkentett mértékben házi feladatot is adtak $(\mathrm{n}=18)$. Ezeknél az iskoláknál figyelhető meg leginkább a tanulók terheinek növekedése. S végül a legnagyobb mértékủ változást azoknál az intézményeknél $(\mathrm{n}=6)$ láttuk, ahol, igazodva a Komplex Alapprogram koncepcióhoz, 2018-tól nem adnak házi feladatot.

Összességében az látható, hogy az új pedagógiai fejlesztési programot bevezető iskolák jelentős részében a meglévő struktúrákat (pl. pedagógiai gyakorlat, tanulásszervezési mód, tartalmi szabályozás kritériumrendszere) nem tudta felülírni a Komplex Alapprogram házi feladat eltörlésére vonatkozó javaslata. A pedagógiai módszertani fejlesztési program - mely az élményközpontúságot állította előtérbe - inspirálta vagy esetenként pedagógiai álláspontjuk megerősítésére késztette az intézményeket, ilyen módon hatott az iskolák gyakorlatára. Ahol az iskolák őrizték korábbi hagyományaikat, a házi feladat gyakoroltató jellege megmaradt, elsősorban az alapkészségek megfelelő szintü elsajátításának szükségességére hivatkozva. Mivel a házi feladat mellőzésére irányuló (eredeti) koncepció nem differenciált a tanulócsoportok életkori, képességbeli sajátosságai alapján, illetve mivel a Komplex Alapprogram teret engedett az intézményspecifikus megoldásoknak, ezért az intézmények maguk alakították ki gyakorlatukat a délutáni idősávban. Többnyire olyan hibrid megoldások alakultak ki, ahol fennmaradt a korábbi gyakorlat, de ezzel egyidőben megjelentek új foglalkozások, új tartalmakkal. Megmaradt az eredményességet szem elött tartó müködési mód (házi feladat), de számos iskolában teret nyert vagy erősödött az élményközpontú tanulásszervezés. Azzal, hogy a Komplex Alapprogram megkérdőjelezte a házi feladat létjogosultságát, erősítette a témára vonatkozó reflexiókat, inspirálta a pedagógiai gondolkodást erről a kérdéskörröl. Intézményvezetők, pedagógusok, szülők párbeszédet kezdtek a házi feladat formáiról és azok előnyeiről, hátrányairól. Szakmai érveket és ellenérveket hoztak fel a tanárok a házi feladat kiadásának gyakorlata ellen és mellett, s mindezt korcsoportokra (évfolyami bontásban) vonatkoztatva tárgyalták.

A szakmai viták eredményeként születtek meg olyan módosító javaslatok, amelyek érintették a házi feladat fogalmát, mennyiségi és minőségi elemeit. Számos intézményben ,gyakorlónak” nevezték el a kiadott feladatokat, melyeket a délutáni idősávban - az iskolában - oldanak meg a gyerekek. A kutatás eredményei azt mutatják, hogy a program koncepciója által javasolt pedagógiai gyakorlatot, miszerint a házi feladat elmélyítő, gyakoroltató funkcióját a délutáni alprogrami foglalkozások váltsák ki, nem lehetett maradéktalanul megvalósítani. Az interjús visszajelzésekből az látható, hogy a pedagógusok elkülönítik az alprogrami foglalkozások élményszerü, játékos világát az alapkészségek gyakoroltatására szánt időkeret formális, szabálykövető jellegétől. Ez utóbbi követi azt a klasszikus formát, mely évtizedek óta a pedagógiai gyakorlat része. Ezt a Komplex Alapprogram új koncepciója sem tudta teljesen felülírni, mégis módosította azt, a házifeladat-adás gyakorlatának átgondolására késztetve igazgatókat, pedagógusokat, szülőket. Másfelől a program is reagált az intézmények visszajelzéseire, melynek eredményeként - a kipróbálási szakaszt követően - változtatott a Komplex Alapprogram megvalósítását vezérlő koncepcionális kereteken.

\section{Támogatás}

Ez a tanulmány az EFOP-3.1.2-16-2016-00001 kódjelü kiemelt projekt keretében valósult meg. 


\section{Irodalom}

Bempechat, J. (2004). The motivational benefits of homework. A social-cognitive perspective. Theory into practice, 43(3), 189-196. DOI: 10.1207/ s15430421tip4303_4

Bempechat, J., Li, J., Neier, S. M., Gillis, C. A. \& Holloway, S. D. (2011). The homework experience. Perceptions of low-income youth. Journal of Advanced Academics, 22(2), 250-278. DOI: $10.1177 / 1932202 \times 1102200204$

Borgonovi, F. \& Montt, G. (2012). Parental involvement in selected PISA countries and economies. OECD Education Working Papers. DOI: 10.1787/5k990rk0jsjj-en

Cooper, H., Jackson, K., Nye, B. \& Lindsay, J. J. (2001). A model of homework's influence on the performance evaluations of elementary school students. The Journal of Experimental Education, 69(2), 181-199. DOI: 10.1080/00220970109600655

Cooper, H., Robinson, J. C. \& Patall, E. A. (2006). Does homework improve academic achievement? A synthesis of research, 1987-2003. Review of Educational Research, 76(1), 1-62. DOI: 10.3102/00346543076001001

Cooper, H. \& Valentine, J. C. (2001). Using research to answer practical questions about homework. Educational psychologist, 36(3), 143-153. DOI: 10.1207/ s15326985ep3603_1

Cosden, M., Morrison, G., Gutierrez, L. \& Brown, M. (2004). The effects of homework programs and after-school activities on school success. Theory into practice, 43 DOI: 10.1207/s15430421tip4303_8

Cummings, C., Dyson, A., Muijs, D., Papps, I., Pearson, D., Raffo, C., Tiplady, L., Todd, L. \& Crowther, D. (2007). Evaluation of the full service extended schools initiative. University of Manchester.

Cummings, C., Dyson, A. \& Todd, L. (2011). Beyond the school gates: Can full service and extended schools overcome disadvantage? Taylor \& Francis. DOI: $10.4324 / 9780203828700$

Deslandes, R. \& Rivard, M.-C. (2013). A Pilot Study Aiming to Promote Parents' Understanding of Learning Assessments at the Elementary Level. School Community Journal, 23(2), 9-32.

Dyson, A. (2011). Full service and extended schools, disadvantage, and social justice. Cambridge Journal of Education, 41(2), 177-193. DOI: 10.1080/0305764x.2011.572864

Dyson, A. \& Kerr, K. (2014). Out of school time activities and extended services in England: A remarkable experiment? Journal for educational research online, 6(3), 76-94.
Eilam, B. (2001). Primary Strategies for Promoting Homework Performance. American Educational Research Journal, 38(3), 691-725. DOI: 10.3102/00028312038003691

Epstein, J. L. \& Voorhis, F. L. van (2001). More than minutes. Teachers' roles in designing homework. Educational psychologist, 36(3), 181-193. DOI: 10.1207/s15326985ep3603_4

European Commission (Ed.) (2010). Early School Leaving: Lessons from research for policy makers. An independent expert report submitted to the European Commission. Network of Experts in Social Sciences of Education and Training.

Falus Iván (1998). Didaktika. Elméleti alapok a tanitás tanulásához. Nemzeti Tankönyvkiadó.

Flecha, R., Pulido, C., Villarejo, B., Racionero, S., Redondo, G. \& Torras, E. (Eds.) (2020). Effects of the use of digital technology on children's empathy and attention capacity. Analytical report. NESET: European Union.

Folkard, A. (2007). Every Parent Matters. 6937-DfESWorking with Parents Covers.

Grolnick, W. S. \& Slowiaczek, M. L. (1994). Parents' involvement in children's schooling: A multidimensional conceptualization and motivational model. Child development, 65(1), 237-252. DOI: 10.2307/1131378

Hammond, C., Linton, D., Smink, J. \& Drew, S. (2007). Dropout risk factors and exemplary programs. A technical report. National Dropout Prevention Center/Network (NDPC/N).

Hoover-Dempsey, K. V., Battiato, A. C., Walker, J. M. T., Reed, R. P., DeJong, J. M. \& Jones, K. P. (2001). Parental involvement in homework. Educational psychologist, 36(3), 195-209. DOI: 10.1207/ s15326985ep3603 5

Imre Anna, Berényi Eszter \& Imre Nóra (2015a). A délután 4-ig tartó iskola bevezetésének első tapasztalatai a terepen. In Anna Imre (Ed.), Eredményesség és társadalmi beágyazottság. Oktatáskutató és Fejlesztő Intézet, 157-193.

Imre Anna, Berényi Eszter \& Imre Nóra (2015b). Az iskolai tanulás időkereteinek és határainak kérdései nemzetközi tapasztalatok tükrében. In Anna Imre (Ed.), Eredményesség és társadalmi beágyazottság. Oktatáskutató és Fejlesztő Intézet, 37-51.

Kozma Tamás (2006). Az összehasonlitó neveléstudomány alapjai. Új Mandátum Kiadó.

Lippman, P. C. (2010). Can the physical environment have an impact on the learning environment? OECD. DOI: $10.1787 / 20727925$ 
Márton Eszter (2019). A szülö és az iskola kapcsolata, szerepe a sikeres együttnevelés megvalósitásában. $\mathrm{PhD}$ disszertáció. Eötvös Lóránd Tudományegyetem Pedagógiai és Pszichológiai Kar Neveléstudományi Doktori Iskola, Budapest. https://ppk.elte.hu/dstore/ document/155/Marton_Eszter_disszertacio.pdf Utolsó letöltés: 2020. 03. 02.

Mihály Ildikó (2003). Beszéljünk a házi feladatról! Új Pedagógiai Szemle, 53(9), 81-91.

Morrison, G. M., Storino, M. H., Robertson, L. M., Weissglass, T. \& Dondero, A. (2000). The protective function of after-school programming and parent education and support for students at risk for substance abuse. Evaluation and Program Planning, 23(3), 365-371. DOI: 10.1016/s0149-7189(00)00025-2

No Child Left Behind (2002). No Child Left Behind Act. US Department of Education.

OECD (2010). The Nature of Learning. DOI: 10.1787/9789264086487-en

OECD (2016-2017). PISA 2015 results. OECD. https:// www.oecd-ilibrary.org/docserver/9789264273856-en. pdf? expires $=1603211329 \& \mathrm{id}=\mathrm{id} \&$ accname $=$ guest $\&$ $\mathrm{ch} \mathrm{e} \mathrm{c} \mathrm{k} \mathrm{s} \mathrm{u} \mathrm{m} \mathrm{=} \mathrm{2810602} \mathrm{A} 58$ E F 7 B 5 E 8 A E 89A351E6F7923 Utolsó megtekintés: 2020. 10. 20. DOI: $10.1787 / 1996377$

OECD (2017a). Emotional well-being of children and adolescents: recent trends and relevant factors (JT03421343). DOI: 10.1787/41576fb2-en

OECD (2017b). Group of National Experts on Effective Learning Environments. OECD Framework for a Module on the Physical Learning Environment. Revised Edition. OECD.

Oláh Attila (1999). A tökéletes élmény megteremtését serkentő személyiségtényezők serdülőkorban. Iskolakultúra, 9(6-7), 15-27.
Patall, E. A., Cooper, H. \& Allen, A. B. (2010). Extending the school day or school year: A systematic review of research (1985-2009). Review of Educational Research, 80(3), 401-436. DOI: $10.3102 / 0034654310377086$

Peters, M., Seeds, K., Goldstein, A. \& Coleman, N. (2008). Parental Involvement in Children's Education 2007. Research Report DCSF-RR034. BMRB International Ltd.

Patall, E. A., Cooper, H. \& Robinson, J. C. (2008). Parent involvement in homework. A research synthesis. Review of Educational Research, 78(4), 1039-1101. DOI: 10.3102/0034654308325185

Ramdass, D. \& Zimmerman, B. J. (2011). Developing self-regulation skills: The important role of homework. Journal of Advanced Academics, 22(2), 194-218. DOI: 10.1177/1932202x1102200202

Révész László \& Mizera Tamás (2018, szerk.). Útmutató. A Komplex Alapprogram intézményi bevezetéséhez. Eszterházy Károly Egyetem - Líceum Kiadó.

Révész László \& Mizera Tamás (2019, szerk.). Útmutató. A Komplex Alapprogram intézményi bevezetéséhez. Eszterházy Károly Egyetem - Líceum Kiadó.

Voorhis, F. L. van (2011). Costs and benefits of family involvement in homework. Journal of Advanced Academics, 22(2), 220-249. DOI: $10.1177 / 1932202 \times 1102200203$

Walker, J. M. T., Hoover-Dempsey, K. V., Whetsel, D. R. \& Green, C. L. (2004). Parental involvement in homework. A review of current research and its implications for teachers, after school program staff, and parent leaders. Harvard Family Research Project, 15, 1-10.

$\mathrm{Xu}$, J. (2015). Investigating factors that influence conventional distraction and tech-related distraction in math homework. Computers \& Education, 81, 304-314. DOI: 10.1016/j.compedu.2014.10.024

\section{Jegyzetek}

${ }^{1}$ „Házi feladat nem javasolt a Komplex Alapprogramban az alsó tagozaton. Az okok közt szerepel annak elkerülése, hogy a tanulót túlterheljük. A gyermeknek szüksége van a tanítási nap utáni szabadidőre, játékra, a családjával való együttlétre.” (Révész és Mizera, 2018. 60.)

${ }^{2}$ A házi feladat a tanuló tanárai által kijelölt feladatok, melyeket a pedagógus azzal a szándékkal ad fel, hogy a tanulók elvégezzék azokat iskolaidőn kívül (Cooper és mtsai, 2006b. 1.).

${ }^{3}$ Az OECD-tagországokban átlagosan 4,9 órát töltöttek a tanulók hetente házi feladat írásával (OECD, 2013-2014. 114.). Hazánk az OECD átlagánál magasabb, 6,2-es értéket mutatott (OECD, 2013-2014. 356.).

${ }^{4}$ A tanulók jólléte azokra a pszichológiai, kognitív, szociális és fizikai tulajdonságokra utal, amelyekre a boldog és teljes élethez szükségük van (OECD, 2016-2017. 19.)

${ }^{5}$ Az elemzők szerint valószínüleg a kulturális tényezők magyarázhatják ezeket az összefüggéseket, mivel a diákok jóllétére az iskolai eseményeken felül más tényezők is hatást gyakorolnak.

${ }^{6}$ Megjegyzendő, hogy a szülői elvárások kulturális kontextusoktól is függenek. Például az ázsiai családokban átlagosnak tekinthető elvárás más kulturális jellemzőkkel leírható társadalmi csoportok esetében túlzott mértékűnek, így kontraproduktívnak bizonyulhatnak. 
${ }^{7}$ A társadalomkritikai megközelítést alkalmazó szociológusok normatív elvárásokat megfogalmazva viszonyulnak a társadalmilag adott valósághoz, és az általuk vallott normáknak megfelelően a társadalom átalakítására törekszenek. Jelen tanulmány szerzői a társadalomkritikai megközelítést tudományos szempontból előítéletesnek tekintik: a kutató a valóságot előzetesen rögzített értékelési eljárások alapján konstruálja, így annak jelenségei nem egyenrangúak számára.

${ }^{8}$ Full Service Extended Schools, FSES = teljes szolgáltatást nyújtó v. kiterjesztett iskolák.

${ }^{9}$ Ennek az angolszász intézményi gyakorlatnak a hazai megfelelőjét az általános iskola alsó tagozatán a napközi, felső tagozatán a tanulószoba intézményében találjuk meg.

${ }^{10}$ Digitális alapú alprogram, Logikaalapú Alprogram, Művészetalapú Alprogram, Életgyakorlat-alapú Alprogram, Testmozgásalapú Alprogram

11 „A Komplex Alapprogram szerint müködő iskolákban sem írásbeli, sem szóbeli házi feladat adása nem javasolt. Ez nem azt jelenti, hogy elmaradhat a szükséges gyakorlás és rögzítés, hanem azt, hogy a pedagógusnak az iskolai tanórákon kell a tanulókkal ezeket a feladatokat elvégezni. Úgy kell a mindennapokban terveznie és megvalósítania az óráit, hogy legyen elegendő idő a szükséges gyakorlásra és az új ismeretek rögzítésére az órák keretén belül.” (Révész és Mizera, 2019. 62.).

${ }^{12}$ A házi feladat fogalma alatt a hazai szaknyelvben azokat a pedagógusok által kiadott feladatokat értjük, melyeket szándékuk szerint a tanuló vagy az iskolában, vagy otthon megold.

${ }^{13}$ A vizsgálat a kipróbálás évében történt, ezért a kutatás eredményei erre az időszakra vonatkoznak.

${ }^{14}$ A Mérés - Értékelés Munkacsoport az intézményméret, a településtípus és a tanulói összetétel alapján alakította ki az intézményi mintát.

${ }^{15}$ Az alminta kiválasztásnál többféle szempontot mérlegeltünk: egyrészt a településtípust, az iskola nagyságát, másrészt az évkezdő pedagógus adatfelvételből származó, a szülőés az iskola viszonyrendszerére vonatkozó adatokat.

16 2011. évi CXC törvény 27. § (2): Általános iskolában a nevelés-oktatást a délelőtti és délutáni tanítási időszakban olyan módon kell megszervezni, hogy a foglalkozások legalább 16 óráig tartsanak, továbbá 17 óráig - vagy addig, amíg a tanulók jogszerüen tartózkodnak az intézményben - gondoskodni kell a tanulók felügyeletéről. Az általános iskola e törvény rendelkezéseinek megfelelően egész napos iskolaként is müködhet.

${ }^{17}$ Egész napos iskola: iskolaszervezési forma, ahol a tanórai és más foglalkozásokat a délelőtti és délutáni időszakra egyenletesen szétosztva szervezik meg, müködését, feltételrendszerét az oktatásért felelős miniszter jogszabályban határozza meg (2011. évi CXC. törvény a nemzeti köznevelésről 4. § [4]).

${ }^{18}$ Az adatok az évzáró intézményvezetői online kérdőíves adatfelvétel eredményeiből (n = 53) származnak. Egy intézményben megjelenhet mindkét tanulásszervezési forma.

${ }^{19}$ A tapasztalatok szerint jellemzően az írásbeli házi feladatok készülnek el, a szóbeli (olvasás, verstanulás stb.) feladatok többnyire otthonra maradnak (Imre és mtsai, 2015a).

${ }^{20}$ Itt mindenekelőtt a tanulmányi eredmények romlását jelezték.

\section{Absztrakt}

Tanulmányunk egyrészt bemutatja, hogy az iskolai házi feladat témakörével foglalkozó nemzetközi szakirodalom milyen koncepciók mentén vizsgálja a házi feladat szerepét az tanulói eredményesség növelése, illetve az esélyegyenlőség biztosítása érdekében. Másrészt felvázoljuk, hogy a házi feladat kérdésköre hogyan jelenik meg a tanórán kívüli tanulás összefüggésében, valamint az otthon és az iskola viszonyrendszerében. A házi feladat iskolai tanulási környezetbe illesztését elsősorban az oktatási intézmények délutáni időszervezésének figyelembevétele, az ismeretek elmélyítését célzó tanórán kívüli feladatadás gyakorlata, valamint az otthoni tanulási környezet szerepe alapján tekintettük át. A Komplex Alapprogramban részt vevő általános iskolákban a házi feladat szerepére irányuló kutatásunk lehetővé tette, hogy feltárjuk az intézményvezetők, a pedagógusok és a szülök véleményét a házi feladat jelentőségéről, szerepéről, szankcionálásáról. Vizsgálatunk eredményei azt mutatják, hogy a Komplex Alapprogram házi feladat eltörlésére irányuló javaslata elindította és/vagy felerősítette a közös gondolkodást a házi feladat adásának gyakorlatáról. Kutatási szempontból érdekes helyzet adódott, ugyanis az intézmények olyan pedagógiai ajánlásokkal találkoztak, melyek követése vagy éppen korrekciója érdekében meg kellett erősíteniük, vagy esetenként ki kellett dolgozniuk szakmai álláspontjukat. Tanulmányunkban többek között bemutatjuk az intézmények eltérő reakcióit a pedagógiai módszertani fejlesztési program házi feladat adást érintő ajánlásaira. 